\title{
Seroepidemiology of leptospirosis in dairy cattle in Ipameri, state of Goiás, Brazil
}

\section{Soroepidemiologia da leptospirose em rebanho bovino leiteiro no municíio de Ipameri, estado de Goiás, Brasil}

\author{
Emily Rocha de Almeida Paim ${ }^{1}$; Andreia Zago Ciuffa ${ }^{2 *}$; Dayane Olímpia Gomes²; \\ Laís Miguel Rezende ${ }^{2}$; Danilo Mundim Silva ${ }^{3}$; Bruno Cabral Pires ${ }^{3}$; Lígia Pinho \\ Cuccato $^{3}$; Thais Fernanda Martins dos Reis ${ }^{3}$; Anna Monteiro Correia Lima ${ }^{4}$
}

\begin{abstract}
Leptospirosis is a disease with worldwide distribution and with risk to human health. In addition, it affects farm animals, and consequently, causes economic losses to farmers. Therefore, understanding the epidemiological profile of the disease in each geographical region is essential. This study was conducted in the rural properties of the municipality of Ipameri, state of Goiás, Brazil, where leptospirosis has not been reported in dairy farming. The objective of this study was to determine the seroprevalence of leptospirosis in dairy cattle, identify the serovars present, and correlate these results with factors that could favor the appearance of the disease. For this purpose, 285 blood samples were collected from dairy cows and microscopic agglutination tests were conducted to identify the 15 serovars of Leptospira interrogans. A structured questionnaire was applied during the visits to the properties to assess the factors associated with leptospirosis. The prevalence was found to be $18.9 \%$, and the serovars present in the region included Hardjo, Wolffi, Canicola, Hebdomadis, Australis, and Icterohaemorrhagiae. The variables associated with leptospirosis were the presence of reproductive changes in the herd, presence of rodents, increased daily production of milk, hired labor, and lower level of education of the producers. Key words: Leptospira. Reproduction. Microscopic agglutination test. Production systems.
\end{abstract}

\section{Resumo}

A leptospirose é uma doença de distribuição mundial, que oferece riscos à saúde humana e acomete os animais de produção, gerando perdas econômicas ao produtor rural, sendo importante conhecer o perfil epidemiológico da doença em cada região. Esse estudo foi realizado em propriedades rurais do município de Ipameri, estado de Goiás, onde não existia nenhum relato sobre a leptospirose na pecuária leiteira. O objetivo desta pesquisa foi determinar a soroprevalência de leptospirose nos bovinos leiteiros, os soravares presentes e correlacionar os resultados com variáveis que podem favorecer o aparecimento da doença. Para isso foram coletadas 285 amostras de sangue de vacas em lactação e realizado o teste diagnóstico de soroaglutinação microscópica em campo escuro (SAM) contra 15 sorovares de Leptospira interrogans. Aplicou-se um questionário estruturado durante a visita para avaliar os fatores associados à ocorrência da leptospirose. A prevalência encontrada foi de $18,9 \%$, e os

\footnotetext{
${ }^{1}$ Médica Veterinária, Universidade Federal de Uberlândia, Uberlândia, MG, Brasil. E-mail: emily_paim@hotmail.com

${ }^{2}$ Discentes do Curso de Mestrado em Ciências Veterinárias, Faculdade de Medicina Veterinária, UFU, Uberlândia, MG, Brasil. E-mail: andreiazago@yahoo.com.br; dayanevet@yahoo.com.br; laismr16@yahoo.com.br

${ }^{3}$ Residentes em Medicina Veterinária Preventiva, UFU, MG, Brasil. E-mail: d_mundim68@hotmail.com; bcabralpires@gmail. com; ligia.cuccato@gmail.com; thais_koro@hotmail.com

${ }^{4}$ Prof $^{\mathrm{a}} \mathrm{Dr}^{\mathrm{a}}$, Faculdade de Medicina Veterinária, UFU, Uberlândia, MG, Brasil. E-mail: annalima@famev.ufu.br

* Author for correspondence
} 
sorovares encontrados foram Hardjo, Wolffi, Canicola, Hebdomadis, Australis e Icterohaemorrhagiae. As características das propriedades associadas à presença da leptospirose foram a presença de alterações reprodutivas, presença de roedores, maior produção diária de leite, mão de obra assalariada, grau de escolaridade inferior do produtor.

Palavras-chave: Leptospira. Reprodução. SAM. Sistemas de criação.

\section{Introduction}

Leptospirosis is a zoonosis that affects all mammals, particularly cattle, pigs, dogs, and humans. It is caused by the bacterium Leptospira interrogans, which has worldwide distribution. The main manifestations of the disease in cattle include reproductive disorders, low milk production, and mortality rate of up to $60 \%$ in young animals, which leads to economic losses to the producers (JULIANO et al., 2000; ADLER; MOCTEZUMA, 2010). The infectious agent may be transmitted through the urine of animals such as rodents, dogs, pigs, and cattle, which serve as disease reservoirs (XUE et al., 2010).

Brazil has a bovine herd of 200 million head, and the state of Goiás has approximately $10.23 \%$ of the total bovine population (IBGE, 2011). Moreover, the weather conditions favor the spread of leptospirosis and contribute to the high prevalence of seropositive animals in this state (BRASIL, 1995).

The disease affects particularly dairy cattle because of the inefficient cattle reproduction in dairy farms, increased involuntary culling of animals, decreased longevity, decreased number of cows for replacement, less genetic progress, and increased spending on insemination and medicines. Furthermore, milk production decreases because of the increased interval between lactations, the dry cow period, and the increase in the proportion of dry cows (BERGAMASCHI et al., 2010). Fávero et al. (2001) and Molnár et al. (1999) reported that the prevalence of leptospirosis in dairy herds was high and reached $56.0 \%$ in the state of Piauí and $65.9 \%$ in the state of Pará.

The municipality of Ipameri has 12,963 dairy cows and dairy farming is one of its major production activities (IBGE, 2006). The dairy farms in the municipality are characterized as having small-scale production, corresponding to 200-1500 liters per day. The municipality has three dairy farms, which sell most of their production in the local market (PMI, 2013).

Considering that no previous studies have evaluated the prevalence and epidemiology of bovine leptospirosis in Ipameri, this study will help monitor animal health and disease control, thereby minimizing the economic losses considering that dairy farming is an important source of income for the municipality.

Therefore, this study aimed to determine the seroprevalence of leptospirosis in dairy cattle herds in the municipality of Ipameri, to identify the serovars present in the region, and to correlate these results with the reproductive history of the herds, production system adopted in the properties evaluated, and environmental factors involved.

\section{Materials and Methods}

\section{Study population}

Ten properties were selected in the municipality of Ipameri, state of Goiás, Brazil, and two criteria were used to select the herds: (i) registration in the Full Bucket Project of the Ipameri municipal administration, and (ii) confirmation of the owner's interest in participating in the study by prior contact. Blood serum samples were collected from all cattle older than 24 months in each property, totaling 285 samples, with a confidence interval of $95 \%$ (95\% CI) and a variation of 5\%, according to Thrusfield (2004). Each property was identified with numbers 1 through 10, according to the order of visitation. 
The geographical coordinates of the properties were: property $1: 17^{\circ} 41^{\prime} 47.74^{\prime \prime} \mathrm{S}$ and $48^{\circ} 7^{\prime} 51.51^{\prime \prime} \mathrm{W}$; property 2: $17^{\circ} 41^{\prime} 37.53$ 'S and $48^{\circ} 22^{\prime} 13.31^{\prime \prime} \mathrm{W}$; property 3: $17^{\circ} 40^{\prime} 47.05^{\prime \prime} \mathrm{S}$ and $48^{\circ} 9^{\prime} 1.25^{\prime \prime} \mathrm{W}$; property 4: $17^{\circ} 44^{\prime} 37.12^{\prime \prime} \mathrm{S}$ and $48^{\circ} 16^{\prime} 28.20^{\prime \prime} \mathrm{W}$; property 5: $17^{\circ} 42^{\prime} 40.03^{\prime \prime} \mathrm{S}$ and $48^{\circ} 8^{\prime} 3.38^{\prime \prime} \mathrm{W}$; property 6: $17^{\circ} 48^{\prime} 58.71^{\prime \prime} \mathrm{S}$ and $48^{\circ} 18^{\prime} 57.27^{\prime \prime} \mathrm{W}$;

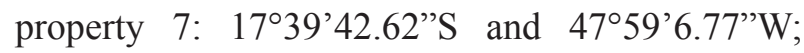
property 8: $17^{\circ} 43^{\prime} 5.10^{\prime \prime} \mathrm{S}$ and $48^{\circ} 14^{\prime} 29.19^{\prime \prime} \mathrm{W}$; property 9: $17^{\circ} 41^{\prime} 17.61^{\prime \prime} \mathrm{S}$ and $48^{\circ} 5^{\prime} 9.53^{\prime \prime} \mathrm{W}$; property 10: $17^{\circ} 41^{\prime} 31.90^{\prime \prime} \mathrm{S}$ and $48^{\circ} 6^{\prime} 54.48^{\prime \prime} \mathrm{W}$.

The properties were visited between October 2013 and March 2014, corresponding to the rainy season in the region (CLIMATOLOGIA, 2015).

\section{Sample collection and analysis}

Blood samples from 285 animals were collected and, after serum removal, were sent under refrigeration to the Infectious Diseases Laboratory of the Faculty of Veterinary Medicine of the Federal University of Uberlândia for examination.

The microscopic agglutination test (MAT) was used, following the protocol of Brasil (1995), against the following $15 \mathrm{~L}$. interrogans serovars present in the biological collection of the laboratory: Australis, Autumnalis, Bataviae, Bratislava, Canicola, Copenhageni, Djasiman, Grippotyphosa, Hardjo, Hebdomadis, Icterohaemorrhagiae, Pomona, Pyrogenes, Tarassovi, and Wolffi.

All serum samples with agglutination $\geq 50 \%$ at a dilution of 1:100 were considered positive and were subjected to increasing dilutions (1:200 to 1:3200) for the determination of the maximum dilution that yielded positive results.
During the visits to the properties, a structured questionnaire was completed by the veterinarian who collected the samples (SANTOS, 2007) to correlate the prevalence of animals that were positive for leptospirosis with the following variables: animal production system, vaccination for leptospirosis, water sources used, presence of reproductive changes, presence of rodents on the property, increased daily milk production, hired labor, and lower level of education of the producers.

\section{Statistical analysis}

The prevalence rate of leptospirosis in the population was calculated using confidence intervals. To determine the effect of the aforementioned variables in disease prevalence, the relative risk (prevalence ratio), confidence interval of the relative risk, and chi-square test were calculated, according to Thrusfield (2004), using BioEstat software version 5.0 (AYRES et al., 2007).

\section{Results}

Of the 285 samples examined using the microscopic agglutination test, 54 were positive in the 1:100 titration for at least one serovar tested, resulting in a prevalence rate of $18.9 \%$ at a confidence interval of $95 \%$. The prevalence rate according to serovar and the presence of antibodies against more than one serovar (coagglutination) are shown in Table 1.

Table 2 shows the percentage of positive cows in each property. Of the 10 farms visited, 8 (80\%) had at least one positive sample. The prevalence in the properties with positive animals ranged from 5.6\% to $69.2 \%$. 
Table 1. Prevalence of anti-Leptospira antibodies per serovar using the microscopic agglutination test in 285 dairy cows in Ipameri, state of Goiás, Brazil, 2014.

\begin{tabular}{lcc}
\hline POSITIVE SEROVARS & No. of positive animals & \% \\
\hline Coagglutination (Hardjo + Wolffi) & 25 & 46.3 \\
Coagglutination (Canicola + Icterohaemorrhagiae) & 4 & 7.4 \\
Canicola & 17 & 31.5 \\
Hardjo & 5 & 9.3 \\
Hebdomadis & 2 & 3.7 \\
Australis & 1 & 1.8 \\
\hline TOTAL & $\mathbf{5 4}$ & $\mathbf{1 0 0}$ \\
\hline
\end{tabular}

Table 2. Spatial distribution of the results of the microscopic agglutination test and the respective serovars by property in dairy cows in Ipameri, state of Goiás, Brazil, 2014.

\begin{tabular}{|c|c|c|c|c|}
\hline \multirow[t]{2}{*}{ PROPERTY } & \multirow{2}{*}{$\begin{array}{c}\text { NUMBER OF } \\
\text { ANIMALS } \\
\text { EXAMINED }\end{array}$} & $\begin{array}{r}\mathrm{N} \\
\text { POSI } \\
\end{array}$ & $\begin{array}{l}\text { OF } \\
\text { IMALS }\end{array}$ & \multirow[t]{2}{*}{ SEROVARS FOUND } \\
\hline & & & $\%$ & \\
\hline 1 & 26 & 18 & 69.2 & Hardjo, Wolffi \\
\hline 2 & 17 & 0 & 0 & - \\
\hline 3 & 17 & 3 & 17.6 & Hardjo, Wolffi \\
\hline 4 & 35 & 2 & 5.7 & Hardjo, Hebdomadis \\
\hline 5 & 18 & 1 & 5.6 & Hebdomadis \\
\hline 6 & 47 & 8 & 17.0 & Australis, Hardjo, Wolffi \\
\hline 7 & 52 & 5 & 9.6 & Hardjo, Canicola, Icterohaemorrhagiae \\
\hline 8 & 25 & 2 & 8.0 & Canicola, Icterohaemorrhagiae \\
\hline 9 & 19 & 0 & 0 & - \\
\hline 10 & 29 & 15 & 51.7 & Canicola \\
\hline TOTAL & 285 & 54 & 18.9 & \\
\hline
\end{tabular}

The prevalence rates in the two by two comparisons between property 1 and the remaining properties differed statistically ( $p<0.05$ ), except for property 10 . The percentage of positive animals in property 6 compared with property 9 was also significantly different $(\mathrm{p}<0.05)$. In addition, property 10 was significantly different $(p<0.05)$ from properties 2-9.

\section{Analysis of the variables}

The analysis of the data obtained from the completed questionnaires from each property indicated that all the properties visited had some characteristics in common, including the semi- extensive production system, absence of animal vaccination for leptospirosis, and absence of adequate treatment of the water source. However, since these characteristics were common to all properties, they could not be associated with the presence of leptospirosis.

The data that differed between the properties included the presence of reproductive changes, presence of rodents, increased daily milk production, hired labor, and lower level of education of the producer. Therefore, it was possible to associate the variables at each property with the occurrence of leptospirosis (Table 3). 
Table 3. Variables associated with the presence of anti-Leptospira antibodies in dairy cows in Ipameri, state of Goiás, Brazil, 2014.

\begin{tabular}{|c|c|c|c|}
\hline VARIABLES & $\begin{array}{l}\text { TOTAL POSITIVE } \\
\text { SAMPLES }(\%)\end{array}$ & RELATIVE RISK (95\% CI) & $\mathbf{p}^{*}$ \\
\hline \multicolumn{4}{|l|}{ Level of education } \\
\hline Elementary education & $28(20.4 \%)$ & $\begin{array}{l}\text { Elementary education - secondary } \\
\text { education: } 0.60(0.36-1.00)\end{array}$ & $\mathrm{p}=0.6$ \\
\hline Secondary education & $16(34.0 \%)$ & $\begin{array}{c}\text { Secondary education - higher education: } \\
3.44(1.69-7.00)\end{array}$ & $\mathrm{p}<0.05$ \\
\hline Higher education & $10(9.9 \%)$ & $\begin{array}{l}\text { Higher education - elementary education: } \\
\qquad 2.06(1.05-4.05)\end{array}$ & $\mathrm{p}<0.05$ \\
\hline \multicolumn{4}{|l|}{ Type of labor } \\
\hline $\begin{array}{l}\text { Hired labor } \\
\text { Family labor }\end{array}$ & $\begin{array}{c}43(27.6 \%) \\
11(8.5 \%)\end{array}$ & $3.23(1.74-6.01)$ & $\mathrm{p}<0.05$ \\
\hline \multicolumn{4}{|c|}{ Average daily milk production } \\
\hline $\begin{array}{l}\leq 500 \text { liters/day } \\
>500 \text { liters/day }\end{array}$ & $\begin{array}{c}6(6.3 \%) \\
48(25.4 \%)\end{array}$ & $4.06(1.80-9.16)$ & $\mathrm{p}<0.05$ \\
\hline \multicolumn{4}{|l|}{ Reproductive changes } \\
\hline $\begin{array}{l}\text { Presence } \\
\text { Absence }\end{array}$ & $\begin{array}{c}53(22.9 \%) \\
1(1.9 \%)\end{array}$ & $12.39(1.75-87.65)$ & $\mathrm{p}<0.05$ \\
\hline \multicolumn{4}{|c|}{ Presence of rodents in the property } \\
\hline $\begin{array}{l}\text { Presence } \\
\text { Absence }\end{array}$ & $\begin{array}{c}52(23.2 \%) \\
2(3.3 \%)\end{array}$ & $7.08(1.77-28.26)$ & $\mathrm{p}<0.05$ \\
\hline
\end{tabular}

$\mathrm{p}=$ probability CI $=$ confidence interval.

$*=$ Chi-square test.

\section{Presence of reproductive changes}

Of the 10 properties studied, seven reported reproductive changes in the herd, characterized by repetitions of heat, dystocia, and abortions. In the properties that presented these changes, $22.9 \%$ of the animals were positive in the MAT (serovars Hardjo and Wolffi), and in the properties without these changes, only $1.9 \%$ of the animals were positive. This difference was significant $(p<0.05)$ and the relative risk was 12.4 (95\% CI, 1.7-87.6).

\section{Presence of rodents on the property}

Disease prevalence was higher when rodents were present $(23.2 \%)$, in contrast to $3.3 \%$ in the absence of rodents. This difference was significantly different $(\mathrm{p}<0.05)$ and the relative risk was 7.1 (95\% CI, 1.7-28.2).

\section{Average daily milk production}

The prevalence of animals positive for leptospirosis was $6.3 \%$ in the properties that produced up to 500 liters of milk per day and $25.4 \%$ in the properties that produced more than 500 liters of milk per day. This difference was significant ( $p$ $<0.05)$ and the relative risk was $4.1(95 \% \mathrm{CI}, 1.8$ 9.2), indicating that the risk of infection in the herds from the properties with increased milk production was 4-fold higher than that in the herds from the properties with lower milk production.

\section{Type of labor}

The analysis of the type of labor indicated that the prevalence rate was $27.6 \%$ in the properties with hired labor, but only $8.5 \%$ in the properties with family labor. This difference was significant using the chi-square test $(\mathrm{p}<0.05)$ and the relative risk was $3.2(95 \% \mathrm{CI}, 1.7-6.0)$. 


\section{Level of education of the producer}

The analysis of the level of education indicated a prevalence rate of $20.4 \%$ where the producers had only primary education, $34 \%$ where the producers had a high school education, and $10 \%$ where the producers had higher education.

The two by two comparisons of this variable indicated no significant difference $(\mathrm{p}>0.05)$ between elementary and high school education. However, a significant difference $(\mathrm{p}<0.05)$ was observed between higher education and elementary education. The relative risk between higher education and primary education was 2.1 (95\% CI, 1.0-4.0) whereas the relative risk between higher education and elementary education was $3.4(95 \%$ CI, 1.7-7.0).

\section{Discussion}

The results of this study allowed the evaluation of the serological and epidemiological profiles of leptospirosis in dairy cattle in the municipality of Ipameri, GO. Surprisingly, the disease prevalence was consistently low in the municipality compared with other municipalities in the state of Goiás, where the reported prevalence of leptospirosis in cattle was $62.2 \%$, with the prevalence of $54.1 \%$ in the areas with a predominance of dairy farms (MARQUES et al., 2010).

The prevalence of seropositive animals was $81.1 \%$ in cattle in the municipality of Goiandira (MOREIRA et al., 2006), adjacent to Ipameri, and $81.9 \%$ in cattle in the microregion of Goiânia in the state of Goiás (JULIANO et al., 2000), which were higher than the rates found in this study, and these authors also primarily worked with lactating cows from dairy farms. The low prevalence observed in the present study may be due to the low number of risk factors on the properties, which indicates that the animals were less exposed to the risk of infection by leptospirosis, and the horizontal transfer of animals between cities was low.
In the state of Mato Grosso do Sul, Madruga et al. (1980) reported a rate of seropositivity to leptospirosis of $74.3 \%$, which was similar to the rate found in cattle by Figueiredo et al. (2009) in the same state $(70 \%)$, suggesting that the infection with Leptospira spp. remained prevalent in the region for more than 3 decades, without any measures to control it. The possible causes for this high positivity are the type of livestock production and ecological factors, the latter including a temperature range between $18.3^{\circ} \mathrm{C}$ and $28.9^{\circ} \mathrm{C}$ and an average rainfall between 1400 and $1600 \mathrm{~mm}$, thus emphasizing how these conditions favor the spread of leptospirosis in the Cerrado region. Ipameri has very similar climatic conditions, with an average rainfall of 1750 $\mathrm{mm}$ and an average annual temperature of $25^{\circ} \mathrm{C}$; therefore, a similar prevalence rate of leptospirosis was expected in this municipality.

It should be emphasized that the blood serum was collected between October 2013 and March 2014 , when the temperature varies between $19.0^{\circ} \mathrm{C}$ and $29.0^{\circ} \mathrm{C}$ and the average rainfall is $202.8 \mathrm{~mm}$, corresponding to the hot and rainy seasons in the region (CLIMATOLOGIA, 2015). Therefore, a higher prevalence was expected in this period because spirochetes can survive for a period of up to 3 weeks in soils containing water puddles formed by precipitation, which makes rainwater an important factor in the transmission cycle of leptospirosis (ESCÓCIO et al., 2010).

All samples that were positive for leptospirosis were found at a dilution of 1:100, and a similar result was found by Campos Júnior et al. (2006), wherein $83.6 \%$ of the positive antibody titers were found in samples with a dilution of 1:100. This result indicates that most animals had contact with spirochetes and developed a humoral response, without necessarily being associated with recent illness or clinical manifestations of the disease (ADLER; MOCTEZUMA, 2010).

The high prevalence rate in properties 1 and 10 indicates that, despite the low prevalence in Ipameri, 
leptospirosis is a current problem and presents a risk of environmental contamination to other properties. For this reason, it is important to apply control measures to avoid the introduction of animals in the herd without quarantine, avoid the presence of wild animals that can serve as disease reservoirs, avoid the slaughter of animals on the property, avoid the use of shared pastures, and immunize the herd using vaccines containing the serovars that are most common in the territory (OLIVEIRA et al., 2010; ARDUINO et al., 2009).

In this study, there were 29 cases of coagglutination, corresponding to 25 serovars of Hardjo and Wolffi and 4 serovars of Canicola and Icterohaemorrhagiae. Coagglutination is relatively frequent among serovars belonging to the same serogroup, as in the case with Hardjo and Wolffi, which belong to the Sejroe group, and even between the members of different serogroups, as reported by Vasconcellos (2004). Moreover, multiple and concomitant infection with several serovars is possible and may have occurred with the coagglutination of Canicola and Icterohaemorrhagiae.

The Hardjo serovar was present in five of the eight properties with seropositive animals in this study; Hardjo is considered the most widespread serovar worldwide and has a major economic impact in the cattle industry because cattle are considered a disease reservoir (CHIARELI et al., 2012).

The prevalence of the Canicola serovar was high in this study, corresponding to $31.5 \%$; however, it was only present in 3 properties. The reservoir for this serovar is dogs (BROD et al., 2005). However, it is not possible to confirm that cattle may have become infected with serotypes coming from dogs because horizontal transmission may occur among cattle.

Among the serotypes found in this study, only Hebdomadis and Australis are not commonly found in commercial vaccines. To increase the effectiveness of immunization, the vaccine should contain the serovars that are most prevalent in the region. The immunity of the vaccine is specific to the serotypes it contains and no cross-reactivity has been observed. Therefore, when multiple serovars infect the animals, the use of polyvalent vaccines is necessary (FAINE, 1982).

The use of untreated water may also contribute to the presence of leptospirosis, and the water source is an important risk factor in the spread of the diseases (COIRO et al., 2011).

In the properties with reproductive changes, $22.9 \%$ animals were positive for leptospirosis. This result suggests that these changes have other causes, including the nutritional status, herd management, and presence of other diseases that affect reproductive efficiency, such as brucellosis, neosporosis, infectious bovine rhinotracheitis, and bovine viral diarrhea (ROCHA, 2003). In addition, the possible absence of detection of antibody titers in the MAT because of abortion should be considered, particularly for the Hardjo serovar, because antibody titers may be very low or negative in disease reservoirs during an abortion (BOLIN, 2003).

The results of this study indicate that the risk of leptospirosis was 7 times higher in the properties where the presence of rodents was reported. Domestic and wild rodents are known to be the main reservoirs of the Icterohaemorrhagiae serovar. Rodents were observed on two properties where this serovar was detected. Therefore, the systematic control of these animals is essential for the maintenance of the health of the cattle herd and human population in this region (ESTEVESMACHADO et al., 2010).

The properties with higher milk production (more than 500L/day) had a higher prevalence of leptospirosis-positive animals, and this could be associated with the higher number of animals in the property, and consequently, with the increased likelihood of environmental contamination and animal infection (MARQUES et al., 2010). 
The rate of positive animals on the properties with family labor was lower than on those with hired labor. The relative risk for this variable was 3.2 , indicating that the properties with hired labor were at a higher risk of infection. The higher level of participation and commitment of the producers may have influenced the decrease in the prevalence of leptospirosis on the properties evaluated.

The education level of the producer may affect the sanitary quality of the herd because the prevalence rate was lower on the properties where the producers had higher education. Similarly, Battaglini et al. (2013) concluded that the higher technification of the farmers has a direct effect on the improvement of milk quality.

The results of this study emphasize the potential risk of occupational infection with leptospirosis. Individuals with direct contact with the infected cattle have increased risk of infection, including veterinarians, property owners, and employees of farms and slaughterhouses. This reinforces the importance of guidance on prophylaxis and control of leptospirosis aiming to decrease the probability of infection.

\section{Conclusions}

The results of this study, including the assessment of the epidemiological aspects of the herds investigated, indicate that the prevalence of leptospirosis in dairy cattle in the municipality of Ipameri was $18.9 \%$ (95\% CI, $14.35 \%-23.45 \%$ ). The serotypes found in the municipality were Hardjo, Wolffi, Canicola, Hebdomadis, Australis, and Icterohaemorrhagiae. Furthermore, a higher prevalence of leptospirosis was associated with the reproductive changes, presence of rodents, increased daily milk production, hired labor, and lower level of education of the producers.

This study was approved by the Animal Ethics Committee of the Federal University of Uberlândia under protocol No. 044/14.

\section{References}

ADLER, B.; DE LA PEÑA MOCTEZUMA, A. Leptospira and leptospirosis. Veterinary Microbiology, Amsterdam, v. 140, n. 3-4, p. 287-296, 2010.

ARDUINO, G. G. C.; GIRIO, R. J. S.; MAGAJEVSKI, F. S.; PEREIRA, G. T. Títulos de anticorpos aglutinantes induzidos por vacinas comerciais contra leptospirose bovina. Pesquisa Veterinária Brasileira, Rio de Janeiro, v. 29, n. 7, p. 575-582, 2009.

AYRES, M.; AYRES JÚNIOR, M.; AYRES, D. L.; SANTOS, A. A. S. BIOESTAT: aplicações estatísticas nas áreas das Ciências Biomédicas. Belém: Sociedade Civil Mamirauá, 2007. 324 p.

BATTAGLINI, A. P. P.; FAGNANI, R.; DUNGA, K. S.; BELOTI, V. Difusão de boas práticas e caracterização de propriedades leiteiras. Archivos de Zootecnia, Córdoba, v. 62, n. 237, p. 151-154, 2013.

BERGAMASCHI, M. A. C. M.; MACHADO, R.; BARBOSA, R. T. Eficiência reprodutiva das vacas leiteiras. São Carlos: EMBRAPA Pecuária Sudeste, 2010. 12 p. (Circular técnica, n. 64).

BOLIN, C. A. Diagnosis and control of bovine leptospirosis. In: WESTERN DAIRY MANAGAEMENT CONFERENCE, 6., 2003, Reno. Anais... Reno: [s.n.], 2003. p. 155-160.

BRASIL. Ministério da Saúde. Fundação Nacional de Saúde. Centro Nacional de Epidemiologia. Coordenação de controle de zoonoses e animais peçonhentos. Manual de Leptospirose. 2. ed. Brasília, 1995. 98 p.

BROD, C. S.; ALEIXO, J. A. G.; JOUGLARD, S. D. D.; FERNANDES, C. P. H.; TEIXEIRA, J. L. R.; DELlagostin, O. A. Evidência do cão como reservatório da leptospirose humana: isolamento de um sorovar, caracterização molecular e utilização em inquérito sorológico. Revista da Sociedade Brasileira de Medicina Tropical, Uberaba, v. 38, n. 4, p. 294-300, 2005.

CAMPOS JÚNIOR, A. C. P.; FRENEAU, G. E.; JULIANO, R. S.; ACYPRESTE, C. S.; DIAS FILHO, F. C.; MARTINS, M. E. Prevalência de anticorpos anti-Leptospira em machos bovinos na microrregião de Goiânia. Ciência Animal Brasileira, Goiânia, v. 7, n. 4, p. 439-446, 2006.

CHIARELI, D.; COSATE, M. R. V.; MOREIRA, E. C.; LEITE, R. C.; LOBATO, F. C. F.; SILVA, J. A.; TEIXEIRA, J. F. B.; MARCELINO, A. P. Controle da leptospirose em bovinos de leite com vacina autógena em Santo Antônio do Monte, Minas Gerais. Pesquisa Veterinária Brasileira, Rio de Janeiro, v. 32, n. 7, p. 633639, 2012. 
CLIMATOLOGIA. Climatempo. São Paulo: [s.n.], 2015. Disponível em: <http://www.climatempo.com.br/ climatologia/89/ipameri-go>. Acesso em: 8 mar. 2015.

COIRO, C. J.; LANGONI, H.; SILVA, R. C. da; ULLMANN, L. S. Fatores de risco para leptospirose, leishmaniose, neosporose e toxoplasmose em cães domiciliados e peridomíciliados em Botucatu-SP. Veterinária e Zootecnia, Botucatu, v. 18, n. 3, p. 393-407, 2011.

ESCÓCIO, C.; GENOVEZ, M. E.; CASTRO, V.; PIATTI, R. M.; GABRIEL, F. H. L.; CHIEBAO, D. P.; AZEVEDO, S. S.; VIEIRA, S. R.; CHIBA, M. Influência das condições ambientais na transmissão da leptospirose entre criações de ovinos e bovinos da região de Sorocaba, SP. Arquivos do Instituto Biológico, São Paulo, v. 77, n. 3, p. 371-379, 2010.

ESTEVES-MACHADO, F. M.; COELHO, H. E.; REZENDE, R. S. Plano de ação para o controle da leptospirose no zoológico municipal de Uberaba-MG. Bioscience Journal, Uberlândia, v. 26, n. 6, p. 981-989, 2010.

FAINE, S. Guidelines for the controlol of leptospirosis. Geneva: Word Health Organization, 1982. 171 p.

FÁVERO, M.; PINHEIRO, S. R.; VASCONCELLOS, S. A.; MORAIS, Z. M.; FERREIRA, F.; FERREIRA NETO, J. S. Leptospirose bovina - variantes sorológicas predominantes em colheitas efetuadas no período de 1984 a 1997 em rebanhos de 21 estados do Brasil. Arquivos do Instituto Biológico, São Paulo, v. 68, n. 2, p. 29-35, 2001.

FIGUEIREDO, A. O.; PELLEGRIN, A. O.; GONÇALVES, V. S. P.; FREITAS, E. B.; MONTEIRO, L. A. R. C.; OliVEIRA, J. M.; OSÓRIO, A. L. A. R. Prevalência e fatores de risco para a leptospirose em bovinos de Mato Grosso do Sul. Pesquisa Veterinária Brasileira, Rio de Janeiro, v. 29, n. 5, p. 375-381, 2009.

INSTITUTO BRASILEIRO DE GEOGRAFIA E ESTATÍSTICA - IBGE. Efetivos dos rebanhos-cabeças. Rio de Janeiro: [s.n.], 2006. Disponível em: $<$ http://www. sidra.ibge.gov.br>. Acesso em: 7 ago. 2014.

. Efetivos dos rebanhos-cabeças. Rio de Janeiro: [s.n.], 2011. Disponível em: $<$ http://www.sidra.ibge.gov. br>. Acesso em: 7 ago. 2014.

JULIANO, R. S.; CHAVES, N. S. T.; SANTOS, C. A.; RAMOS, L. S.; SANTOS, H. Q.; MEIRELES, L. R.; GOTTSCHALK, S.; CORRÊA FILHO, R. A. C. Prevalência e aspectos epidemiológicos da leptospirose bovina em rebanho leiteiro na microrregião de GoiâniaGo. Ciência Rural, Santa Maria, v. 30, n. 5, p. 857-862, 2000.
MADRUGA, C. R.; AYCARDI, E.; PUTT, N. Frequência de aglutininas anti-Leptospira em bovinos de corte na região Sul de cerrado do Estado de Mato Grosso. Arquivos da Escola de Veterinária da UFMG, Belo Horizonte, v. 32, n. 2, p. 245-249, 1980.

MARQUES, A. E.; ROCHA, W. V.; DE BRITO, W. M. E. D.; FIORAVANTI, M. C. S.; PARREIRA, I. M.; JAYME, V. D. S. Prevalência de anticorpos anti-Leptospira spp. e aspectos epidemiológicos da infecção em bovinos do Estado de Goiás. Ciência Animal Brasileira, Goiânia, v. 11, n. 3, p. 607-617, 2010.

MOLNÁR, E.; NEGRÃO, A. M.; MOLNÁR, L. Dados sorológicos da leptospirose bovina em algumas regiões do estado do Pará. Revista Brasileira de Reprodução Animal, Belo Horizonte, v. 23, n. 3, p. 406-407, 1999.

MOREIRA, R.; CABRAL, D. D.; OLIVEIRA, P. R.; LIMA, A. L. C. Levantamento da prevalência sorológica para Leptospira interrogans em vacas leiteiras na região de Goiandira-GO. Veterinária Notícias, Uberlândia, v. 12, n. 2, p. 103, 2006.

OLIVEIRA, F. C. S.; AZEVEDO, S. S.; PINHEIRO, S. R.; BATISTA, C. S. A.; MORAES, Z. M.; SOUZA, G. O.; GONÇALES, A. P.; VASCONCELlOS, S. A. Fatores de risco para a leptospirose em fêmeas bovinas em idade reprodutiva no Estado da Bahia, Nordeste do Brasil. Pesquisa Veterinária Brasileira, Rio de Janeiro, v. 30, n. 5, p. 398-402, 2010.

PREFEITURA MUNICIPAL DE IPAMERI - PMI. Histórico da região/município de Ipameri: aspectos físicos e geográficos. Ipameri: [s.n.], 2014. Disponível em: <http://www.ipameri.go.gov.br>. Acesso em: 16 ago. 2014.

ROCHA, W. V. Soroprevalência, distribuição regional e fatores de risco da brucelose em fêmeas bovinas adultas no Estado de Goiás. 2003. Dissertação (Mestrado em Sanidade Animal) - Escola de Veterinária, Universidade Federal de Goiás, Goiânia.

SANTOS, J. P. D. Soroprevalência e aspectos epidemiológicos da leptospirose caprina no Município de Uberlândia, MG. 2007. Dissertação (Mestrado em Ciências Veterinárias) - Faculdade de Medicina Veterinária, Universidade Federal de Uberlândia, Uberlândia.

THRUSFIELD, M. Epidemiologia veterinária. 2. ed. São Paulo: Roca, 2004. 572 p. 
VASCONCELlOS, S. A. Laboratory diagnosis XUE, F.; DONG, H.; WU, J.; WU, Z.; HU, W.; SUN, A.; of leptospirosis in animals. In: SIMPOSIO TROXELL, B.; YANG, X. F.; YAN, J. Transcriptional INTERNACIONAL SOBRE LEPTOSPIRA Y LEPTOSPIROSIS EN LAS AMÉRICAS, 2004, Cidade do México. Anais... Cidade do México: División Educación Contínua de la Universidad Nacional Autónoma de México, 2004. v. 1, p. 70-76. responses of Leptospira interrogans to host innate immunity: significant changes in metabolism, oxygen tolerance, and outer membrane. PLOS Neglected Tropical Diseases, Londres, v. 4, n. 10, p. e857, 2010. 